\title{
PENERAPAN MEDIA BALOK UNTUK MENINGKATKAN KEMAMPUAN BELAJAR HURUF HIJAIYAH PADA KELOMPOK B3 PAUD SANDHY PUTRA TELKOM TERNATE
}

\author{
${ }^{1}$ Pipih Sofia, ${ }^{2}$ Bahran Taib \\ ${ }^{1}$ Guru PAUD Sandhy Putra Telkom Ternate \\ ${ }^{2}$ Dosen PAUD FKIP Unkhair \\ baharulfa@yahoo.co.id.
}

\begin{abstract}
This research came from a background of the need of using Playing Blocks method to increase children's creativity in learning process at Kindergarten. This research had a purpose to know the use of playing blocks method in increasing the student hijaiyah learning capability at Group B TK Sandhy Putra Telkom Ternate.This research used the class room action research which was carried out Group B at TK. Sandhy Putra Telkom Ternate by 2 cycles. This research used qualitative approach to get data and analized by observation sheet, observation rating, teachers and students documentation.The research result showed that in the first cycle, the criteria of success rate reached $47,06 \% \quad(10$ students) from 28 students, meanwhile in the second cycle, the criteria of success rached $78,6 \%$ (22 students). Thus, it can be concluded that playing block improved the student hijaiyah learning capability.
\end{abstract}

Keywords: Playing blocks media, hijaiyah, learning capability

\section{PENDAHULUAN}

Pasal 1 ayat 14 tahun 2003 tentang Sistem Pendidikan Nasional menjelaskan bahwa pendidikan anak usia dini adalah suatu upaya pembinaan yang ditujukan kepada anak sejak lahir sampai usia 6 tahun yang dilakukan melalui memberi rangsangan pendidikan untuk membantu pertumbuhan dan perkembangan jasmani dan rohani agar anak memiliki kesiapan dalam memasuki pendidikan yang lebih lanjut (Depdiknas, USPN, 2004:4). Di dalam pertumbuhan dan perkembangan anak, ada beberapa kemampuan yang harus dirangsang oleh orang tua atau guru antara lain yaitu: fisik motorik, bahasa, kognitif, sosial emosional, seni, nilai-nilai agama dan moral (NAM).

Salah satu bidang pengembangan kemampuan dasar di anak usia dini adalah nilai-nilai agama dan moral. Banyak orang tua yang tidak sadar bahwa nilai-nilai agama dan moral itu sangat penting bagi kehidupan anak usia dini atau bagi kita semua, terutama dalam belajar mengaji atau mengenal huruf hijaiyah. Mengajarkan huruf hijaiyah pada anak usia dini tidaklah mudah karena dunia mereka adalah dunia bermain. Maka perlu digunakan media dalam pembelajaran yang dapat membantu anak untuk belajar salah satu media yang dapat membantu anak 
mengenal huruf hijaiyah adalah media balok. Main balok adalah sebuah mainan yang terbuat dari kayu, biasanya sangat disukai oleh anak karena dengan bermain balok bisa melatih kreativitas, daya ingat dan juga mengenal konsep, mengembangkan motorik halus pada anak. Dapat juga digunakan untuk belajar mengenalkan huruf hijaiyah pada anak usia dini.

Berdasarkan observasi, mengenal huruf hijaiyah sangat sulit diajarkan kepada anak TK usia 4-6 tahun, berdasarkan kondisi di lapangan maka peneliti merasa perlu menggunakan media balok yang didesain berwarna-warni dengan cara bermain balok yang menyenangkan bagi anak.

Berdasarkan permasalahan di atas , maka peneliti berkeinginan untuk melakukan penelitian dengan judul "Penerapan Media Balok untuk Meningkatkan Kemampuan Belajar Huruf Hijaiyah di Kelompok B diTK Sandhy Putra Telkom Ternate”

Identifikasi Masalah, anak kurang tertarik untuk belajar mengenal huruf hijaiyah.dan kesulitan guru dalam mengajarkan huruf hijaiyah bagi anak. Adapun rumusan masalahnya yaitu apakah dengan penggunaan media balok dapat meningkatkan kemampuan belajar huruf hijaiyah pada siswa kelompok B3 di TK Sandhy Putra Telkom Ternate?.

Tujuan penelitian adalah untuk meningkatkan kemampuan mengenalkan huruf hijaiyah di TK Sandhy Putra Telkom Ternate dengan media balok. Adapun manfaat penelitian ini bagi siswa yaitu siswa akan mengenal huruf hijaiyah sejak dini karena dengan pembelajaran tersebut secara langsung anak akan bisa membaca Iqro' dan Al- qur'an. Manfaat bagi guru yaitu dapat menambah wawasan, dan kreativitas dalam menciptakan media pembelajaran. Manfaat bagi sekolah adalah untuk meningkatkan mutu atau kualitas sekolah dalam kegiatan pembelajaran diTK Sandhy Putra Telkom Ternate.

Penelitian ini dilakukan dengan asumsi bahwa: (1) TK Sandhy Putra belum mampu menerapkan media balok untuk mengenalkan huruf hijaiyah pada anak usia dini. (2) Guru mampu menerapkan permainan balok bagi siswa. (3) Siswa mampu menguasai huruf hijaiyah melalui permainan balok.

Ruang lingkup dan batasan masalah pada penelitian ini adalah cara menungkatkan kemampuan bejar huruf hijaiyah pada Kelompok B TK Sandhy Putra Telkom Ternate tahun ajaran 2015/2016 dengan jumlah siswa 28 orang.

Definisi Istilah penelitian untuk menghindari perbedaan atau kesalah pahaman terhadap judul dan masalah penelitian. Huruf Hijaiyah merupakan huruf penyusun kata dalam Al Qur an. Seperti halnya di Indonesia yang memilki huruf alfabet dalam menyusun sebuah kata menjadi kalimat, huruf hijaiyah juga memiliki peran yang sama. Media balok adalah sebuah alat permainan yang terdiri dari berbagai bentuk ada yang segi empat, segitiga, lingkaran dengan berbagai warna atau berwarna polos yang digunakan sebagai media pembelajaran di TK yang dicetak huruf hijaiyah pada sisinya. 
Media pembelajaran adalah alat bantu dalam proses kegiatan belajar mengajar atau segala sesuatu yang bisa merangsang pikiran, perasaan, perhatian kemampuan dalam berfikir anak. Media pembelajaran bisa menggunakan buku, film, video dan sebagainya.

Ciri-ciri umum dari media pembelajaran menurut Hamalik (1994:12), yaitu: media pembelajaran identik dengan pengertian peragaan, tekanan utama terletak pada benda atau hal-hal yang dapat dilihat dan didengar, digunakan dalam rangka hubungan (komunikasi) dalam pengajaran antara guru dan siswa, semacam alat bantu belajar mengajar, merupakan suatu "perantara" (medium, media) dan digunakan dalam rangka belajar, mengandung aspek, sebagai alat dan sebagi teknik yang erat pertaliannya dengan metode belajar.

Secara umum, manfaat media dalam proses pembelajaran adalah memperlancar interaksi antara guru dengan siswa sehingga pembelajaran akan lebih efektif dan efisien. Pengelompokan media pendidikan menurut karakteristiknya yaitu: media asli dan media tiruan, media grafis, media bentuk papan, media yang disorotkan, media dengar, media pandang dengar (audio-visual aids) dan media cetak.

Adapun kriteria yang harus diperhatikan guru dalam penggunaan media pembelajaran, yaitu: media yang digunakan sesuai dengan tujuan pembelajaran, media yang digunakan sesuai karakteristik materi pelajaran, media yang digunakan sesuai dengan keadaan siswa, kemampuan guru dalam menggunakan media, media yang digunakan dapat meningkatkan motivasi belajar siswa, media yang digunakan bervariasi dan inovatif dan media yang digunakan hendaknya cukup dikenal audience (siswa) atau bersifat kontekstual

Balok adalah salah satu media pembelajaran yang dapat diterapkan pada anak usia dini karena konsep pembelajaran anak usia dini bermain sambil belajar. Bermain balok susun merupakan salah satu alat bermain konstruksi yang bermanfaat untuk anak. Tidak hanya untuk aspek kognitif, motorik, tetapi juga untuk meningkatkan kecerdasan emosi anak (EQ). Balok huruf hijaiyah adalah sebuah permainan yang terbuat dari kayu yang berbentuk segi empat yang berwarna polos atau berwarna-warni yang di sisi-sisinya bertulisan huruf-huruf hijaiyah.

Menurut Akhmad Solihin (2014:10 ) beberapa kelebihan bermain balok antara lain: (1) Pada kegiatan bermain balok, anak belajar melakukan aktivitas dengan prosedur dan tahapan kerja, Sistematika berfikir anak tentang bangun dan ruang anak terbentuk dengan lebih cepat dan lebih baik, (2) Anak dapat belajar dan memiliki kemampuan untuk menyatukan sebuah perencanaan, (3)Anak dapat terdorong dengan positif untuk bekerja dalam sebuah struktur bersama, (4) Kemampuan anak melakukan pemetaan (mapping) mendorong tumbuhnya kemampuan berpikir simbolik, sehingga mengembangkan juga kemampuan berbahasa anak menjadi lebih meningkat dan semakin terstruktur. 
Kekurangan dalam bermain balok yaitu : balok harus banyak sesuai dengan jumlah anak, anak kurang sabar dalam menuggu giliran pada saat bermain balok dan anak tidak mau berbagi dengan teman.

Pintar membaca huruf hijaiyah adalah modal utama anak agar bisa dan lancar membaca Al-qur'an. Karena Al-qur' an tersusun dari huruf-huruf hijaiyah. Untuk belajar Al-qur'an mulai dari yang paling mudah,yaitu dengan mengenal huruf hijaiyah terlebih dahulu. Ada 3 aspek penting dalam pembelajaran kepada anak khususnya dalam pembelajaran huruf hijaiyah, adalah kemudahan, menyenangkan dan visual.

Kemampuan mengenal huruf hijaiyah adalah penguasan dalam mengenal huruf-huruf hijaiyah berdasarkan bentuk, bunyi dan cara pengucapannya sebelum membaca Al- qur'an.

\section{METODE PENELITIAN}

Penelitian ini adalah penelitian tindakan kelas atau Classroom Action Research, guna mengetahui penggunaan media balok huruf hijaiyah untuk meningkatkan kemampuan belajar huruf hijaiyah pada kelompok B TK Shandy Putra Telkom Ternate. Desain yang digunakan dalam penelitian ini mengacu pada model Kemmis dan M.C Taggart (dalam Depdiknas, 1999) bahwa PTK yang dikembangkan terdiri atas 4 fase kegiatan yang meliputi: perencanaan (plan), pelaksanaan tindakan (action), observasi (observation), dan refleksi (reflection).

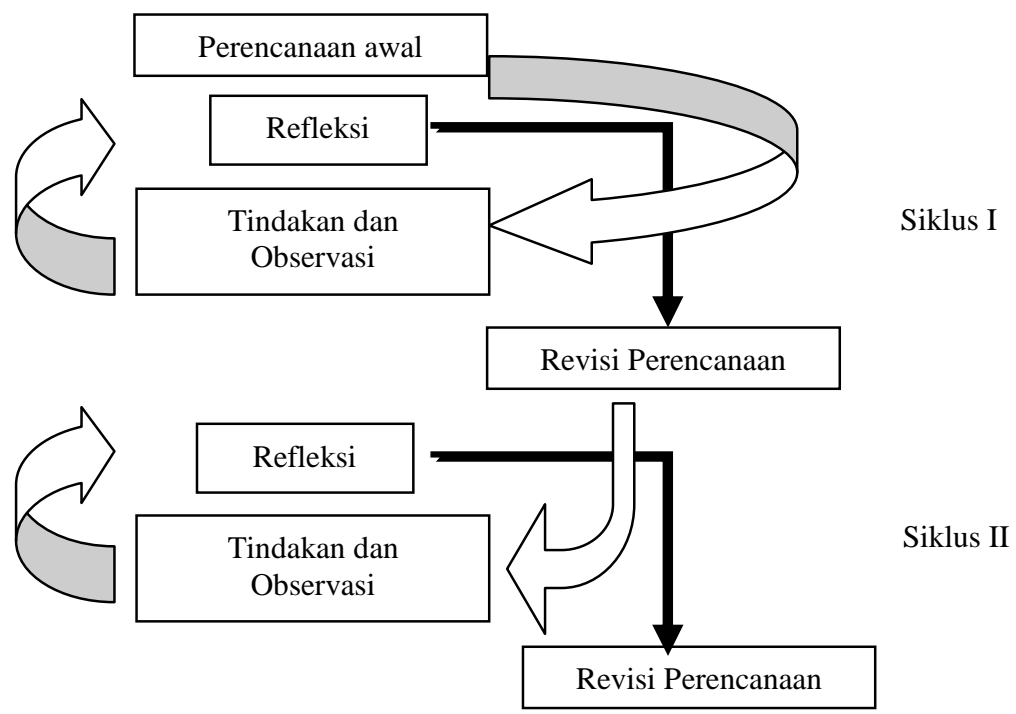

Gambar: Tahapan Siklus PTK Menurut Kemmis \& Mc Tegart

(Sumber: Kunandar, 2008) 
Sumber data dalam penelitian ini sebagai informan atau narasumber yaitu siswa kelompok B3 Sandhy Putra Telkom Ternate dengan jumlah 28 siswa dan guru kelompok B. Jenis data yang digunakan adalah kualitatif berupa nilai perolehan hasil pengamatan kemampuan siswa yang dinyatakan dengan skor 4 (Memenuhi Kompetensi Sangat Baik), skor 3 (Sudah Memenuhi Kompetensi), skor 2 (Mulai Memenuhi Kompetensi), dan skor 1 (Belum Memenuhi Kompetensi). Sedangkan data yang diperoleh yaitu dari hasil observasi, hasil evaluasi, dan dokumentasi.

Pengumpulan data yang di lakukan dalam penelitian ini adalah observasi, catatan lapangan dan evaluasi. Tahap-tahap yang ditempuh dalam penelitian ini mencakup: 1) tahap perencanaan dan 2) tahap tindakan. Pelaksanaan tindakan dalam penelitian ini sesuai dengan jenis penelitian yang dipilih yaitu penelitian tindakan kelas dengan pendekatan kualitatif. Kegiatan pendekatan ini melalui 2 siklus. Setiap siklus terdiri dari empat fase yaitu: 1) rencana tindakan (plan), 2) pelaksanaan (action), 3) observasi (observation), 4) refleksi (reflecting).

Analisis data dalam penelitian ini dilakukan selama proses, yang berarti bahwa pelaksanaannya sudah dimulai sejak pengumpulan data dan dikerjakan secara insentif ,yaitu sesudah meninggalkan lapangan ( Moleoang, 2004 ). Sedangkan teknik yang digunakan analisis data kualitatif yang dikembangkan Miles dan Humerman (Corebima, 2010:79 ) yang terdiri dari tiga tahap kegiatan yang dilakukan secara berurutan. Tahap-tahap analisis data tersebut adalah: 1) mereduksi data, 2) menyajikan data, 3) menarik kesimpulan dan verivikasi.

Kriteria keberhasilan diukur dengan ketuntasan belajar dan daya serap. Untuk mengetahui ketuntasan dan daya serap, maka diperlukan adanya analisis observasi, hasil karya, evaluasi akhir proses pembelajaran setiap akhir tindakan.

Dari hasil observasi kegiatan pembelajaran pada penilaian perkembangan anak, dapat dirumuskan untuk menentukan persentase sebagai berikut:

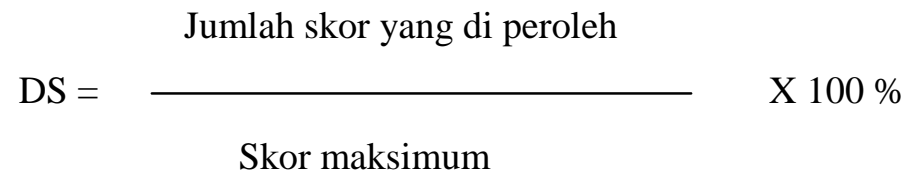

Kriteria penilaian keberhasilan tindakan ditentukan pada pencapaian perkembangan anak. Simbol penilaian yang dipakai di TK adalah:

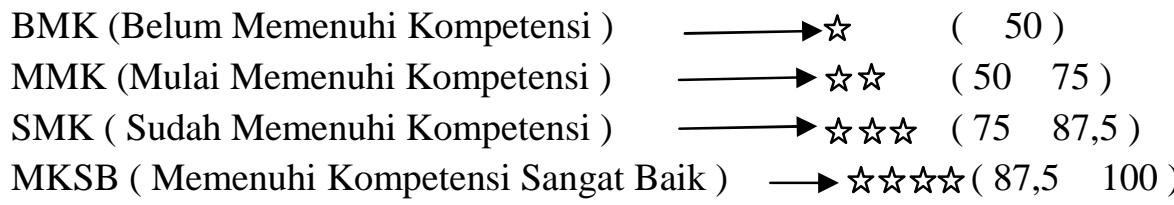




\section{PEMBAHASAN}

Penelitian tindakan kelas ini dilaksanakan 2 siklus karena pada siklus I ketuntasan belajar siswa belum memnuhi harapan peneliti yaitu belum mencapai $75 \%$, sehingga dilanjutkan pada siklus II.

Pada siklus I dilakukan 3 kali pertemuan. Berdasarkan hasil penilaian pada siklus I diketahui bahwa keberhasilan aktivitas pada siklus I adalah 10 siswa atau $35,7 \%$ dari 28 siswa yang dikategorikan tuntas, sedangkan 18 siswa atau 64,3\% dikategorikan tidak tuntas.

Gambar Diagram 4.2 Rekapitulasi hasil persentase siswa siklus I

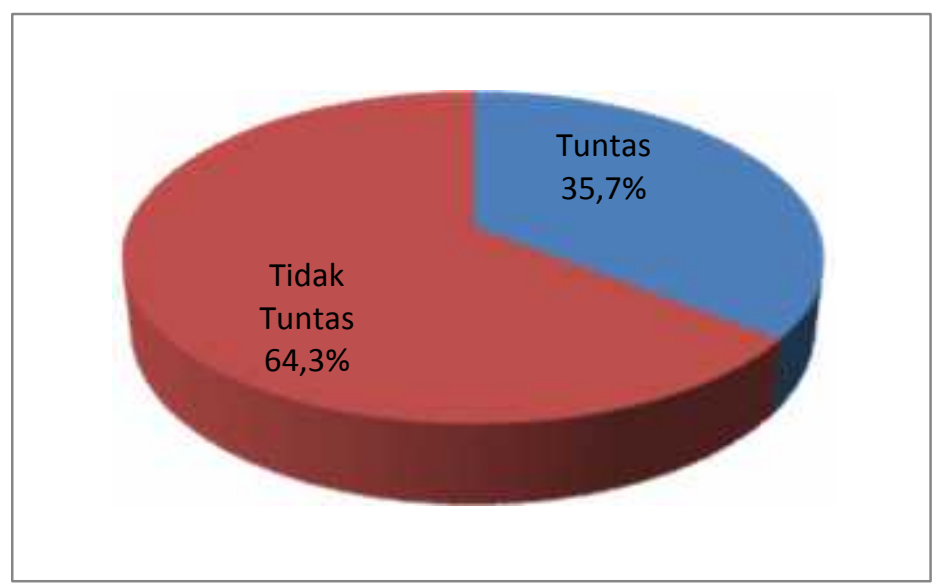

Siswa yang belum mencapai keberhasilan atau belum mencapai standar kompetensi dalam mengembangkan kemampuan memahami huruf hijaiyah dikarenakan pemahaman anak dalam pengenalan huruf hijaiyah masih kurang, seringnya anak tidak masuk sekolah, kurang memperhatikan guru dan ramai sendiri. Guru masih kurang menciptakan suasana pembelajaran yang menyenangkan.

Sehingga dapat disimpulkan bahwa pada siklus I aspek keberhasilannya masih $35,7 \%$ belum memenuhi minimal keberhasilan anak yaitu $75 \%$. Jadi, hasil tersebut belum sesuai dengan apa yang diharapkan peneliti. Maka diperlukan perbaikan, antara lain: dalam penyampaian materi guru menggunakan bahasa yang sederhana mungkin agar anak lebih mudah memahami. Menambah lebih banyak lagi kotak huruf hijaiyah, dan menciptakan suasana belajar yang menyenangkan sehingga anak dapat antusias semangat dalam mengikuti kegiatan. 
Berdasarkan hasil evaluasi siklus I belum memenuhi kriteria keberhasilan yang diharapkan peneliti yaitu $75 \%$, maka perlunya dilanjutkan pada siklus II. Pada siklus II, dilakukan 3 kali pertemuan. Berdasarkan hasil penilaian siswa pada proses pembelajaran siklus II sudah ada peningkatan dibanding siklus I. pada siklus II ini siswa yang mencampai tingkat ketuntasan adalah 22 siswa atau 78,6\% yang termasuk kategori baik dengan peningkatan $42,9 \%$. Siswa yang tidak tuntas adalah 6 siswa atau $21,4 \%$.

Gambar Diagram 4.6 Rekapitulasi hasil persentase siswa pada siklus II

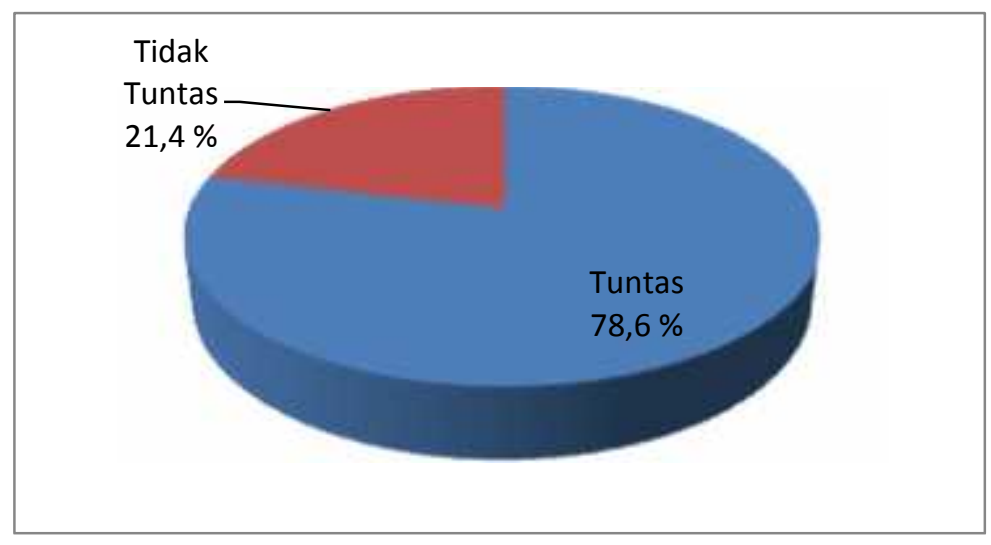

Hasil dari penelitian siklus II, menunjukan adanya peningkatan hasil belajar anak didik dari siklus I. peningkatan hasil belajar memenuhi tujuan yang diharapkan oleh peneliti yaitu mencapai stdandart ketuntasan $75 \%$.. Dengan menggunakan media balok dalam pembelajaran, mengalami peningkatan dalam kemampuan mengenal huruf hijaiyah. Pengelolaan dalam pembelajaran atau pada kegiatan berlangsung guru sudah dapat menciptakan suasana yang menyenangkan. Sehingga anak-anak lebih bersemangat untuk belajar mengenal huruf hijaiyah . Keaktifan siswa dalam mengikuti pembelajaran sudah lebih baik. Siswa sudah fokus memperhatikan guru. Kemampuan siswa dalam mengenal huruf hijaiyah sudah lebih baik.

Dari hasil penelitian pada siklus I dan II, menunjukkan bahwa media balok dapat meningkatkan kemampuan mengenal huruf hijaiyah pada siswa kelompok B, khususnya kelas B3 TK Sandhy Putra Telkom Ternate tahun pelajaran 2015/2016. Hal ini dapat dilihat dari nilai hasil belajar yang diperoleh melalui evaluasi yang dilaksanakan pada akhir siklus yang digunakan untuk mengukur seberapa besar keberhasilan yang dicapai. 
Hasil Evaluasi Siklus I dan II

\begin{tabular}{|l|c|c|c|c|}
\hline $\begin{array}{c}\text { Tingkat } \\
\text { Keberhasilan }\end{array}$ & Jumlah Siswa & Siklus I (\%) & Jumlah Siswa & $\begin{array}{c}\text { Siklus II } \\
(\%)\end{array}$ \\
\hline Tuntas & 10 & 35,7 & 22 & 78,6 \\
\hline Tidak tuntas & 18 & 64,3 & 6 & 21,4 \\
\hline
\end{tabular}

Dari tabel di atas dapat dilihat ketuntasan belajar siswa pada siklus I cukup baik, dan mengalami peningkatan ketuntasan belajar pada siklus II dapat dilihat pada diagram di bawah ini:

Gambar Diagram 4.11 Hasil Evaluasi Siklus I dan Siklus II

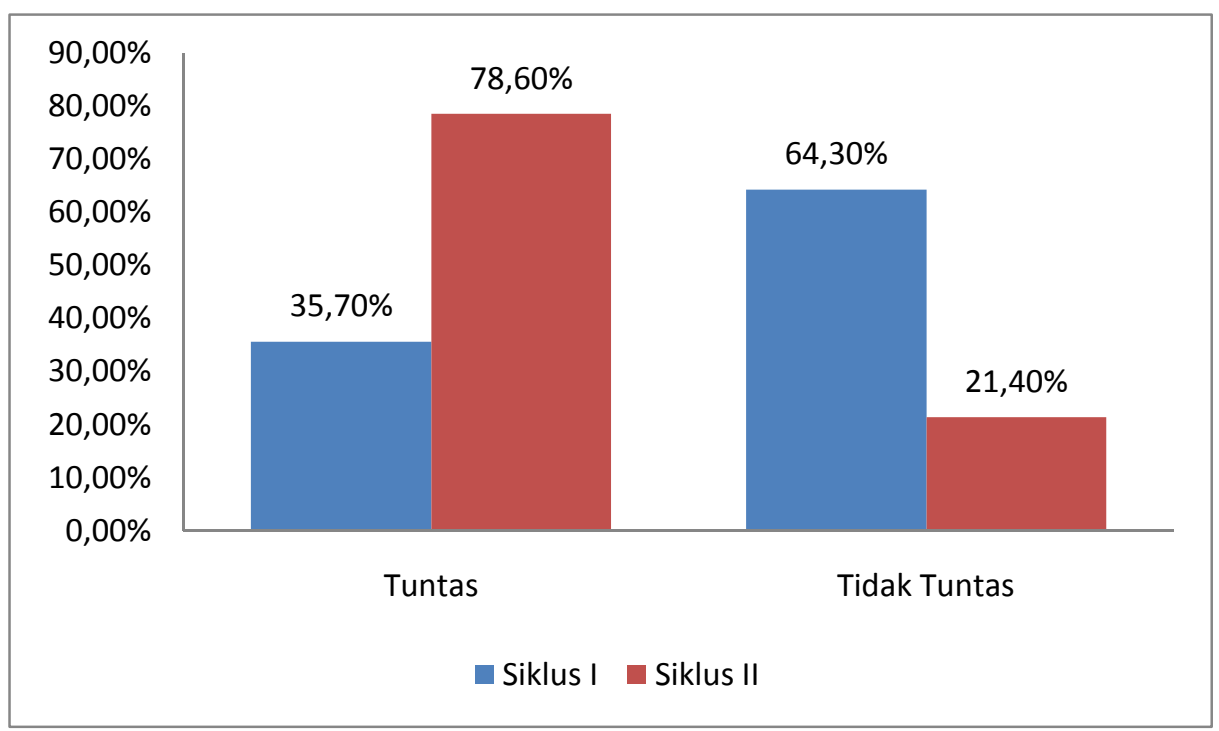

Berdasarkan pada diagram di atas dapat dilihat bahwa ketuntasan belajar sudah baik, terjadi kenaikan dari siklus I ke siklus II. Pada siklus I ketuntasan belajar 35,7\% (10 siswa) terjadi peningkatan pada siklus II menjadi 78,6\% (22 siswa). Itu artinya terjadi peningkatan sebesar 42,9\%, sementara 6 siswa masih belum tuntas yaitu NN, DA, AM, MZ, CH, dan D. Faktor utama dari 6 siswa yang masih belum tuntas adalah kurang memperhatikan materi pembelajaran yang disampaikan peneliti.

Kemampuan anak kelas B3 TK Shandy Putra Telkom Ternate sudah baik. Peningkatan ketuntasan belajar anak siklus I dilanjutkan siklus II berjalan sesuai dengan harapan oleh peneliti kerena kettuntasan belajar siswa sudah mencapai $75 \%$, sehingga tidak perlu dilanjutkan pada siklus berikutnya. 


\section{SIMPULAN}

Dari hasil kesimpulan yang dianalisis dapat disimpulkan bahwa melalui permainan balok huruf hijaiyah dapat mingkatkan kemampuan memahami huruf hijaiyah pada anak kelompok B3 TK Shandy Putra Telkom Ternate tahun ajaran 2016/2017. Ini ditunjukkan dengan hasil evaluasi dengan peningkatan pada siklus I dimana 10 siswa atau 35,7\% dari 28 siswa yang dikatagorikan tuntas, sedangkan 18 siswa atau $64,3 \%$ dikategorikan tidak tuntas. Kemudian meningkat pada siklus II ini siswa yang mencampai tingkat ketuntasan adalah 22 siswa ataui 78,6\% yang termasuk kategori baik dengan peningkatan $42,9 \%$. Siswa yang tidak tuntas adalah 6 siswa atau $21,4 \%$.

Adapun saran bagi Guru, sebagai pendidik harus mampu dalam merencanakan, melaksanakan dan mengevaluasi program pembelajaran. Dimana tiga kegiatan sangat penting dan saling erat hubungannya. Saran bagi lembaga PAUD, diharapkan kepada pihak sekolah agar dapat menggunakan media balok huruf hijaiyah dalam perkembangan pembelajaran memahami huruf hujaiyah. Saran bagi peneliti selanjutnya, disarankan untuk membuat atau menciptakan model pembelajarn baru dalam pembelajaran memahami huruf hijaiyah selain dengan menggunakan metode balok seperti yang peneliti sudah lakukan. Atau mengembangkan metode balok pada materi pembelajaran lainnya, seperti penggunaan metode balok dalam pembelajaran memahami huruf abjad dan sebagainya.

\section{DAFTAR PUSTAKA}

Arikunto. S. 2001. Dasar-Dasar Evaluasi Pendidikan. Jakarta: Bumi Aksara.

Akhmad Solihin. 2014. Fungsi dan Manfaat Bermain Balok. (Online). Tersedia : http://paud-anakbermainbelajar.blogspot.co.id/2014/10/fungsi-dan-manfaatbermain-balok-block.html. (01 juni 2016).

Aqib, Zainal. 2010. Profesionalisme Guru dalam Pembelajaran. Surabaya: Insan Cendekia.

Arsyad, Azhar. 2011. Media Pembelajaran. Jakarta: PT Raja Grafindo Persada.

Corebima, AD, dkk. 2010. Penelitian Tindakan Kelas. LepKhair.

Depdiknas, 2006. Kurikulum 2004 Standar Kompetensi Taman Kanak-Kanak dan Raudlatul Atfal. Jakarta: Depdiknas.

Depdiknas. 2010. Kumpulan Pedoman Pembelajaran Taman Kanak-Kanak. Jakarta: Ditjen Kemendiknas.

Sudarna. 2012. Pendidikan Anak Usia Dini Berkarakter. Jakarta: PT Elex Media Komputindo. 
Fajarwati Elli. 2009. Hubungan Antara Alat Permainan Balok dengan Kreativitas Anak TK.

Freeman dan munandar . 1997. Bermain dan Belajar. Jakarta: PT Grasindo.

Hamalik, Oemar. 1994. Media Pendidikan. Bandung: Citra Adtya Bakti.

Kemp, J.E. \& Dayton. D.K. 1985. Planning and Producing Instrutional Media (Fifth Edition). New York : Harper \& Row. Publishers.

Nurfadilah. 2014. Mengenal Huruf Hijaiyah dengan Permainan yang Menyenakan untuk Anak Taman Kanak-Kanak. (Online). Tersedia: http://tkalirsyadpwt.blogspot.co.id/2014/03/mengenal-huruf-hijaiyahdengan-berbagai.html. (01 Juni 2016).

Sadiman, Arief S. 1993. Media Pendidikan. Jakarta: Raja Grafindo Persada.

Sudjana, N. 2001. Penilaian Hasil Proses Belajar Mengajar. Bandung: PT. Remaja Rosdakarya.

Smaldino, Sharon E.; Deborah L. Lowther; dan James D. Russell. 2011. Intructional Technology and Media For Learning (Teknologi Pembelajaran dan Media Untuk Belajar). Diterjemahkan oleh Arif Rahman. Jakarta: Kencana Prenada Media Group.

Susilana, Rudi. 2009. Sumber Belajar dalam Pendidikan. Dalam Ilmu dan Aplikasi Pendidikan, Bagian II: Ilmu Pendidikan Praktis. Bandung: PT. Imperial Bhakti Utama (Halaman 197 - 220).

Undang Undang RI Nomor 20 Tahun 2003 Tentang Sistim Pendidikan Nasional. 